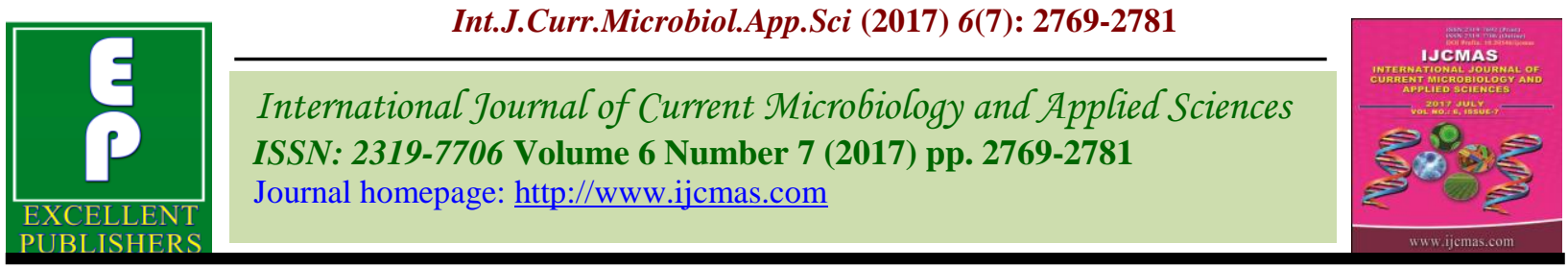

Original Research Article

https://doi.org/10.20546/ijcmas.2017.607.387

\title{
Production and Improvement of Alkaline $\alpha$ - Amylase by Bacterial Isolate from Chilika Lake
}

\author{
Allampalli Sirisha, Sonali Priyadarshini* and Pratima Ray \\ Department of microbiology, C.B.S.H., Orissa University of Agriculture and Technology, \\ Unit 7, Surya Nagar, Bhubaneshwar, Odisha-751003, India \\ *Corresponding author
}

\section{A B S T R A C T}

Keywords

Solid state

fermentation,

Bacillus sp,

Alkaline $\alpha-$

amylase, UV

induced mutation,

Sediment sample.

Article Info

Accepted:

29 June 2017

Available Online:

10 July 2017
The present study suggest that the Chilika Lake isolate i.e., Bacillus sp. may act as a potent strain for alkaline $\alpha$ - amylase production. In case of parent strain the enzyme production was higher with banana peels as the substrate; in case of mutant, potato peels used as substrate. Optimization of the fermentation parameters and the use of suitable carbon, nitrogen and metal chloride supplements resulted in increase in the enzyme yield. The enzyme production was significantly high at optimum temperature which was found to be $37{ }^{\circ} \mathrm{C}$ and the optimum inoculums size $2 \%$. Maximum production was found when the medium is supplemented with starch as carbon source, yeast extract as nitrogen source and $\mathrm{NaCl}$ as mineral chloride. The enzyme was found to be active over a wide range of $\mathrm{pH}$ and showed the optimum activity at $\mathrm{pH} \mathrm{11.} \mathrm{This} \mathrm{isolate} \mathrm{both} \mathrm{wild} \mathrm{and}$ mutant could thus be industrially exploited for the synthesis of alkaline $\alpha$ - amylase which have immense industrial application.

\section{Introduction}

$\alpha$-Amylases (1-4, $\alpha$ D- glucanohydrolase EC 3.2.1.1) are extracellular endo-enzymes that hydrolyze internal $\alpha-1-4-$ glycosidic linkage in starch and related substrate in an endofashion producing oligosaccharides, glucose and $\alpha$-limit dextrin (Fogarty et al., 1999). Alpha-amylases find potential applications in pharmaceuticals, baking, brewing, textile, paper, syrup industries and detergent manufacturing processes (Bajpai and Bajpai, 1989; Hewitt and Solomons, 1996; Sivaramakrishnan et al., 2006). In recent years, the market of detergent additive enzymes is one of the largest markets for industrial enzymes (Niehaus et al., 1999; Schallmey et al., 2004). Several enzymes such as alkaline protease, cellulase, lipase and amylase are usually put in detergents as additives (Niehaus et al., 1999; Horikoshi, 2006). Amylases are the second type of enzymes used in the formulation of enzymatic detergent and $90 \%$ of all liquid detergents contain these enzymes (Gupta et al., 2003). These enzymes are used in detergents for laundry and automatic dishwashing to degrade the residues of starchy foods such as potatoes, gravies, custards and chocolates to dextrin and other smaller oligosaccharides 
(Mukherjee et al., 2009). Amylases having activity at alkaline $\mathrm{pH}$ maintain the necessary stability under detergent conditions (Kirk et al., 2002).

Removal of starch from surfaces is also important in providing a whiteness benefit, since starch can be an attractant for many types of particulate soils. Termamyl ${ }^{\circledR}$ (Novozymes) derived from Bacillus licheniformis and its derivative Duramyl ${ }^{\circledR}$ (Novozymes) have been used for that purpose (Olsen and Falholt, 1998). Duramyl ${ }^{\circledR}$ (Novozymes) was developed by site-direct mutagenesis. UV- light has also been reported to be mutagenic in variety of organisms and in recent years, attempts have been made for the overproduction of microbial enzyme by induced mutagenesis (Singh et al., 2011). The present investigation deals with the enhancement of the production of $\alpha$-amylase by subjecting the isolate to mutagenesis by UV radiation.

\section{Materials and Methods}

\section{Sample collection and analysis}

Sediment sample was collected from Chilika Lake i.e. Balugaon in sterile plastic polythene and brought to the Department of Microbiology, O.U.A.T., Bhubaneswar (Odisha) for further study. The $\mathrm{pH}$ (Akpor et $a l ., 2006$ ) and moisture content (Jackson, 1967) were calculated accordingly.

\section{Bacterium and growth conditions}

The bacterial culture was isolated on nutrient agar medium, $\mathrm{pH} 9.0$ and one colony was selected and re-streaked on nutrient agar plate to check the purity of the culture and then maintained in nutrient agar slants for further experiments. The isolate was checked for amylolytic activity based on zone of clearance on starch agar plate and named as CHB7.

\section{Mutagenesis}

Bacterial suspension $(0.5 \mathrm{ml})$ was transferred to sterile nutrient agar plates and exposed to UV irradiation (260-270nm) for 5, 10, 15, 20, $25,30,35,40,45,50,55$ and $60 \mathrm{~min}$. The distance between lamp and petri-plates was adjusted to $55 \mathrm{~cm}$. UV exposed plates were placed in the incubator at $37{ }^{\circ} \mathrm{C}$ for $24 \mathrm{~h}$. Colonies of CHB7 isolate after UV treatment were recorded to determine survival of the target strain. Sub culturing of resistant colonies was done and then re-exposed to UV irradiation to obtain mutant colonies. The screened mutant derivatives were assayed quantitatively for alkaline $\alpha$-amylase activity by plate assay method (Singh et al., 2013).

\section{Qualitative analysis of enzyme production}

Qualitative analysis of enzyme production by 3 mutants was performed at $\mathrm{pH} 6.0$ - 12.0 and based on the highest zone of clearance only one potent isolate was selected for further study.

\section{Partial characterization of bacterial isolates}

After screening, the amylase producing isolates (parent and mutant) were subjected for partial characterization by cultural (color, texture, margin, elevation and size), morphological (Gram variability), standard biochemical tests (Lysine, TSI, Arginine, Ornithine, Mannitol motility, Indole, Methyl Red, Voges-Proskauer, Citrate, Nitrate, Esculin, Urease). The results were analyzed in PIBWin Software (Bryant, 2003) for probabilistic identification.

\section{Preparation of inoculum}

A volume of $100 \mathrm{ml}$ of nutrient broth taken in a $250 \mathrm{ml}$ Erlenmeyer flask was inoculated with a loop full of cells from a 24 h old slant 
and kept at $37{ }^{\circ} \mathrm{C}$ in a bacterial incubator. After $18 \mathrm{~h}$ of incubation, $1 \mathrm{ml}$ of this nutrient broth culture was used as the inoculum.

\section{Solid state fermentation}

Agro residues: Rice Husk (RH), Rice Bran (RB), Potato Peels (PP), Banana Peels (BP), Sugarcane Bagasse (SCB), Corn Cob (CC) and Cauliflower Stalk (CS) were collected from local market, Siripur. They were properly washed and chopped into small pieces. The residues were separately spread on trays and oven dried at $70{ }^{\circ} \mathrm{C}$ for $24 \mathrm{~h}$ (Unakal et al., 2012). After grinding into fine powdered form, they were preserved at room temperature. Agro residues (2.5 g) were kept separately in a $250 \mathrm{~mL}$ Erlenmeyer flask and then moistened with $10 \mathrm{~mL}$ mineral salt medium to $75 \%$ moisture content and sterilized at $121^{\circ} \mathrm{C}$ for $15-20 \mathrm{~min}$. Media supplemented with peptone $0.6 \%, \mathrm{KCl} 0.05 \%$ (w/v), $\mathrm{MgSO}_{4} .7 \mathrm{H}_{2} \mathrm{O} 0.05 \%$ (w/v) and starch (1.0\%), pH 9.0 was used for amylase production for target bacterial strain along with screened mutant. The fermentation process was started by adding $1 \mathrm{~mL}$ of overnight bacterial culture. The contents of the flasks were mixed thoroughly to ensure uniform distribution of the inoculum and incubated at $37^{\circ} \mathrm{C}$ for 24 to $48 \mathrm{~h}$ with occasional gentle shaking (Sajjad and Choudhry, 2012). Both parent (CHB7) and mutant $(\mathrm{MCH} / 40)$ strains were analyzed for enzyme production under different physical and cultural conditions.

\section{Enzyme extraction}

After 24-48 h incubation, $20 \mathrm{~mL} \quad 0.05 \mathrm{M}$ sodium phosphate buffer ( $\mathrm{pH}-8.0)$ was added to $1 \mathrm{~g}$ fermented carrier, the mixture was shaken for $1 \mathrm{~h}$ at $37^{\circ} \mathrm{C}$ and $150 \mathrm{rpm}$ on a rotary shaker, filtered with muslin cloth and centrifuged at $10,000 \mathrm{rpm}$ at $4^{\circ} \mathrm{C}$ for $15 \mathrm{~min}$. The supernatant was used as the crude enzyme (Sajjad and Choudhry, 2012).

\section{Assay of enzyme activity}

\section{DNSA method (quantitative assay)}

Quantitative assay for amylase activity was carried out by measuring the amount of reducing sugar according to the DNSA method (Miller, 1959). Amylase activity was determined by incubating a mixture of $1 \mathrm{ml}$ of aliquot of each enzyme source and $1 \%$ soluble starch dissolved in $0.05 \mathrm{M}$ sodium phosphate buffer, at $\mathrm{pH} 8.0$, at $37 \mathrm{C}$ for $20 \mathrm{~min}$. The reaction was stopped by adding $1.5 \mathrm{ml}$ of 3, 5Di-nitro salicylic acid, and then followed by boiling for $5 \mathrm{~min}$ at $99.8^{\circ} \mathrm{C}$ at water bath. The final volume was made up to $4.5 \mathrm{ml}$ with distilled water and the reducing sugar released was measured at $540 \mathrm{~nm}$. One unit of amylase activity was defined as the amount of enzyme that releasing $1 \square$ mol maltose equivalent per minute under the assay conditions. Reducing sugar (maltose) concentration was determined from a standard curve under same condition using maltose.

\section{Amylase activity $((\mathrm{IU} / \mathrm{mL}) / \mathrm{min})$}

$$
=\frac{\text { Amount of sugar released } \times 1000}{\text { mol.wt of maltose xtime of incubation }}
$$

\section{Estimation of protein concentration}

The protein concentration was estimated by using Bovine serum albumin as standard (Lowry et al., 1951).

\section{Optimization at different period of fermentation}

As production of enzyme is well correlated with the period of fermentation, the effect of fermentation period on amylase production was carried out. Varied fermentation period of $24,48,72,96,120 \mathrm{~h}$ of the bacterial isolate were carried $37{ }^{\circ} \mathrm{C}$ in the assay medium for amylase production and amylase activity was 
found out for both parent (CHB7) and mutant $(\mathrm{MCH} / 40)$ strains.

\section{Optimization of $\mathrm{pH}$ for amylase production}

The effect of $\mathrm{pH}$ on amylase production of both parent (CHB7) and mutant $(\mathrm{MCH} / 40)$ strains was determined by growing the isolates in the assay medium with different $\mathrm{pH}$ values ranging from 6.0-12.0. The amylase assay was carried out by the method described earlier.

\section{Optimization at different temperature condition}

The effect of different temperatures an amylase production by both parent (CHB7) and mutant $(\mathrm{MCH} / 40)$ were determined by growing in assay media at varied temperatures (17, 37 and $\left.47{ }^{\circ} \mathrm{C}\right)$. In this experiment the $\mathrm{pH}$ and time of incubation remains constant at 9.0 and $96 \mathrm{~h}$ for the bacterial isolate. The amylase activity was carried out to determine the concentration of the enzyme.

\section{Optimization at different inoculum size of fermentation}

As production of enzyme is well correlated with the inoculum size, the effect of inoculum size on amylase production was carried out. Varied inoculum size $(1-5 \mathrm{ml})$ was used. In the assay medium for amylase production and amylase activity was found out for parent (CHB7) and mutant (MCH/40) strains.

\section{Optimization at different Carbon Sources}

To study the effect of different carbon sources (glucose, fructose, lactose, mannitol, starch, sucrose, dextrose, xylose) both parent (CHB7) and mutant $(\mathrm{MCH} / 40)$ strains were inoculated into the assay medium with different carbon sources at $\mathrm{pH}-9.0$ at $37{ }^{\circ} \mathrm{C}$ for $96 \mathrm{~h}$ incubation to find out amylase activity under different cultural conditions.

\section{Optimization at different Nitrogen sources}

To ascertain the effect of culture conditions on amylase production, the study was carried out at different nitrogen sources like peptone, yeast extract, casein, urea, $\mathrm{NaNO}_{3}$, $\left(\mathrm{NH}_{4}\right)_{2} \mathrm{SO}_{4}$. In this experiment, both parent (CHB7) and mutant (MCH/40) were inoculated in respective assay medium containing different nitrogen sources with $\mathrm{pH}$ 9.0 at $37{ }^{\circ} \mathrm{C}$ in a incubator for $96 \mathrm{~h}$ to obtain a uniform growth.

\section{Optimization at different metal chlorides ions}

Amylase activity was assayed in the presence of $10 \mathrm{mM}$ metal chlorides $\left(\mathrm{NaCl}, \mathrm{ZnCl}_{2}\right.$, $\mathrm{MgCl}_{2}, \mathrm{MnCl}_{2}, \mathrm{CaCl}_{2}$, and $\mathrm{FeCl}_{3}$ ).

\section{Thin layer chromatography (TLC)}

Soluble starch (amylose) (1\%) was digested with amylase in sodium phosphate buffer $\mathrm{pH}$ 8.0 at $37^{\circ} \mathrm{C}$ for 45 minutes. Previously chilled ethanol was added to the enzyme and substrate mixture to stop the reaction. The end products were then analyzed on silica gel 60 (GF254) (Merck) thin-layer chromatography. After developing the products with a solvent system of butanol-acetic acid-water $(3: 1: 1)$ by volume, the spots were visualized by spraying it with $20 \%$ Sulphuric acid in ethanol and baking it in an oven at $120{ }^{\circ} \mathrm{C}$ for $30 \mathrm{~min}$. The procedure of Aygan et al., (2008) with slight modification was followed.

\section{Results and Discussion}

The $\mathrm{pH}$ and moisture content of the Chilika sediment was found to be 9.0 and $80 \%$ respectively which shows that the sample is alkaline. The parent isolate showed big, 
white, oval shape colony with flat elevation, irregular margin and rough texture. It was gram negative and endospore positive. It was observed that parent strain isolate CHB7 showed a zone of clearance of $6 \mathrm{~mm}$ on starch agar plate at $\mathrm{pH} 9.0$ and 10.0 by hydrolyzing the starch, indicating the production of alkaline amylase by the isolate. The parent strain CHB7 was exposed to UV-radiation for various time lengths. Further the resistant were sub cultured followed by starch agar plate assay at $\mathrm{pH}$ 9.0. From table 1 it was evident that the parent strain was mutated after being exposed to UV radiation and showed good starch hydrolysis which was proved by the different zone of clearance shown by mutant strain. Among all mutants; $\mathrm{MCH} / 20, \mathrm{MCH} / 40$ and $\mathrm{MCH} / 50$ showed highest zone of clearance, which were 9, 9 and $8 \mathrm{~mm}$ respectively.

From the qualitative estimation results obtained for amylase by all the bacterial isolates, it was obtained that mutant (MCH/40) showed highest enzymatic activity as shown in table 2. Therefore biochemical test and enzymatic assay were carried out taking parent (CHB7) and the mutant (MCH/40) strains (Table 3). From table 4, it was observed that sugar utilization results for both parent and mutant strains were the same. From the biochemical and sugar utilization tests the organism (Parent and mutant) was identified as Bacillus sp.

The standard curve of maltose and the protein concentrations are presented below in figures 1 and 2 respectively.

Table.1 Zone of clearance shown by mutant strains after treatment with U.V radiation

\begin{tabular}{|c|c|c|}
\hline Sl.no. & $\begin{array}{c}\text { Name of the isolate based on } \\
\text { time of exposing } \\
\text { U.V radiation (min) }\end{array}$ & Net zone of hydrolysis* \\
\hline 1. & $\mathrm{MCH} / 5$ & 5.0 \\
\hline 2. & $\mathrm{MCH} / 10$ & 6.0 \\
\hline 3. & $\mathrm{MCH} / 15$ & 6.0 \\
\hline 4. & $\mathrm{MCH} / 20$ & 9.0 \\
\hline 5. & $\mathrm{MCH} / 25$ & 5.0 \\
\hline 6. & $\mathrm{MCH} / 30$ & 7.0 \\
\hline 7. & $\mathrm{MCH} / 35$ & 9.0 \\
\hline 8. & $\mathrm{MCH} / 40$ & 5.0 \\
\hline 9. & $\mathrm{MCH} / 45$ & 8.0 \\
\hline 10. & $\mathrm{MCH} / 50$ & 5.0 \\
\hline 11. & $\mathrm{MCH} / 55$ & 3.0 \\
\hline 12. & $\mathrm{MCH} / 60$ & \\
\hline
\end{tabular}

*Each value is the average of three replicates. 
Table.2 Starch plate assay by parent and mutant strains at various $\mathrm{pH}$

\begin{tabular}{|c|c|c|c|c|c|c|c|}
\hline \multirow{2}{*}{ Isolates } & \multicolumn{7}{|c|}{ Zone of clearance in $(\mathbf{m m}) *$} \\
\cline { 2 - 8 } & $\mathbf{p H 6 . 0}$ & $\mathbf{p H 7 . 0}$ & $\mathbf{p H ~ 8 . 0}$ & $\mathbf{p H ~ 9 . 0}$ & $\mathbf{p H ~ 1 0 . 0}$ & $\mathbf{p H ~ 1 1 . 0}$ & pH 12.0 \\
\hline Parent & 2.0 & 4.0 & 5.0 & 6.0 & 6.0 & 9.0 & 10.0 \\
\hline $\mathrm{MCH} / 20$ & 4.0 & 4.0 & 6.0 & 9.0 & 9.0 & 10.0 & 11.0 \\
\hline $\mathrm{MCH} / 40$ & 2.0 & 2.0 & 5.0 & 10.0 & 8.0 & 9.0 & 13.0 \\
\hline $\mathrm{MCH} / 50$ & 2.0 & 6.0 & 6.0 & 10.0 & 9.0 & 10.0 & 12.0 \\
\hline
\end{tabular}

*Each value is the average of three replicates.

Table.3 Biochemical tests for parent and mutant

\begin{tabular}{|c|c|c|c|c|c|c|c|c|c|c|c|c|c|}
\hline Strains & In & MR & VP & Ci & NR & Es & Orn & Lys & Ur & Mani & Mo & TSI & Arg \\
\hline $\begin{array}{c}\text { Parent } \\
\text { CHB7 }\end{array}$ & - & + & - & - & + & + & - & - & + & + & - & + & + \\
\hline $\begin{array}{c}\text { MutantM } \\
\text { CH/40 }\end{array}$ & - & + & - & + & + & + & - & + & + & + & + & + & + \\
\hline
\end{tabular}

In- Indole test; MR- Methyl red test; VP- Voges Proskauer test; Ci- Citrate utilisation; NRNitrate reductase; Ur- urease test; Es- Esculin hydrolysis; Mo- Motility test; Man-manitol; TSItriple sugar iron test; Arg- arginine; Orn- Ornithine; Lys- Lysine; (+): Positive; (-): Negative

Table.4 Sugar utilization tests

\begin{tabular}{|c|c|c|c|c|c|c|c|c|}
\hline Strains & Glucose & Sucrose & Xylose & Mannose & Cellobiose & Salicin & Galactose & Inositol \\
\hline $\begin{array}{c}\text { Parent } \\
\text { CHB7 }\end{array}$ & + & + & - & - & - & - & - & - \\
\hline $\begin{array}{c}\text { Mutant } \\
\text { MCH/40 }\end{array}$ & + & + & - & - & - & - & - & - \\
\hline
\end{tabular}

Fig.1

Fig 1 Maltose standard curve

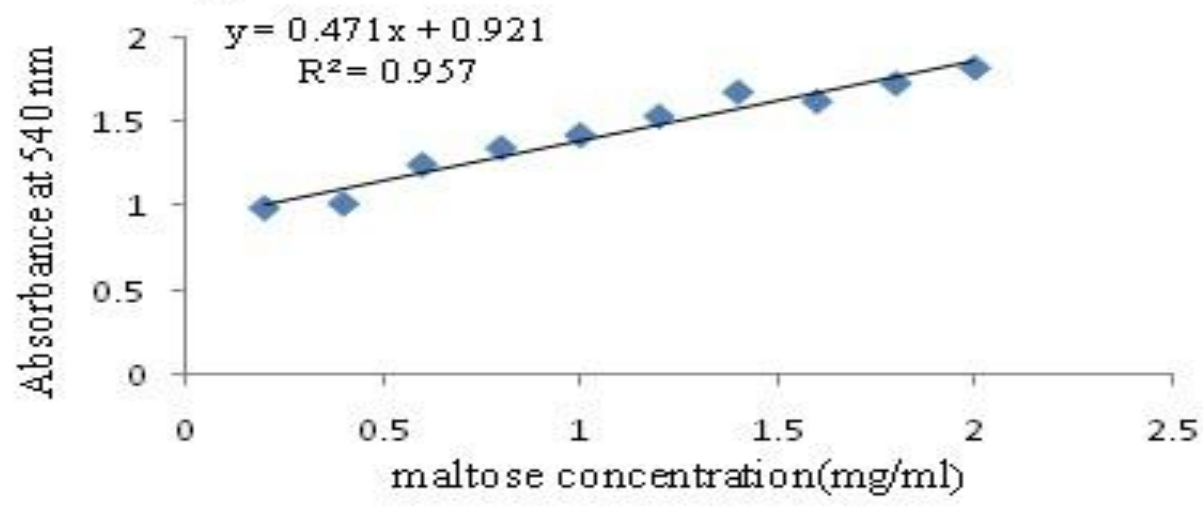


Fig.2

Fig. 2 Protein estimation standard curve

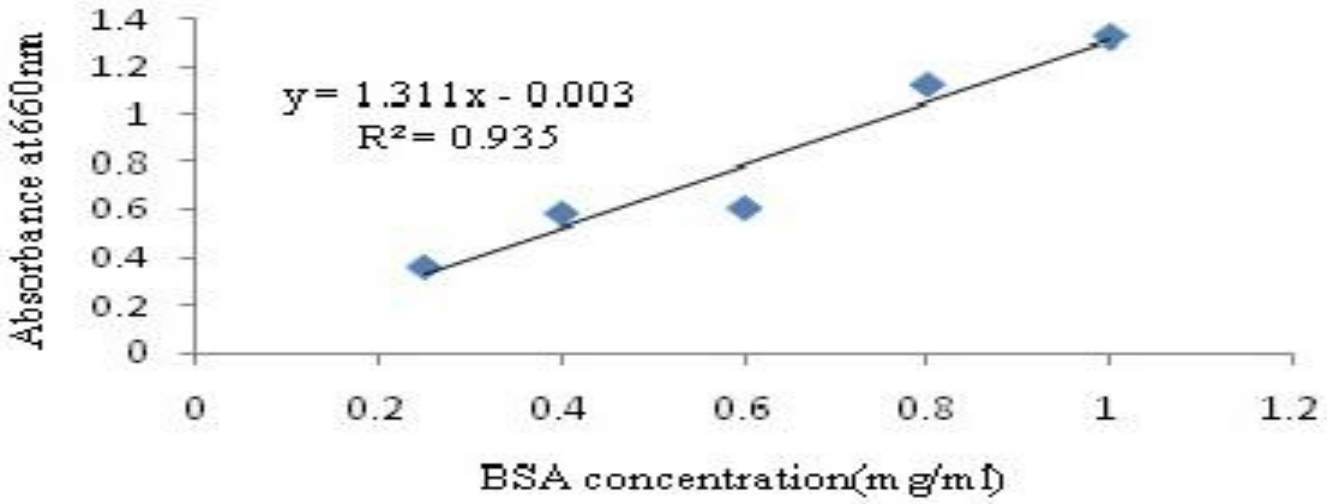

Fig.3 Effect of fermentation period on parent and mutant strains

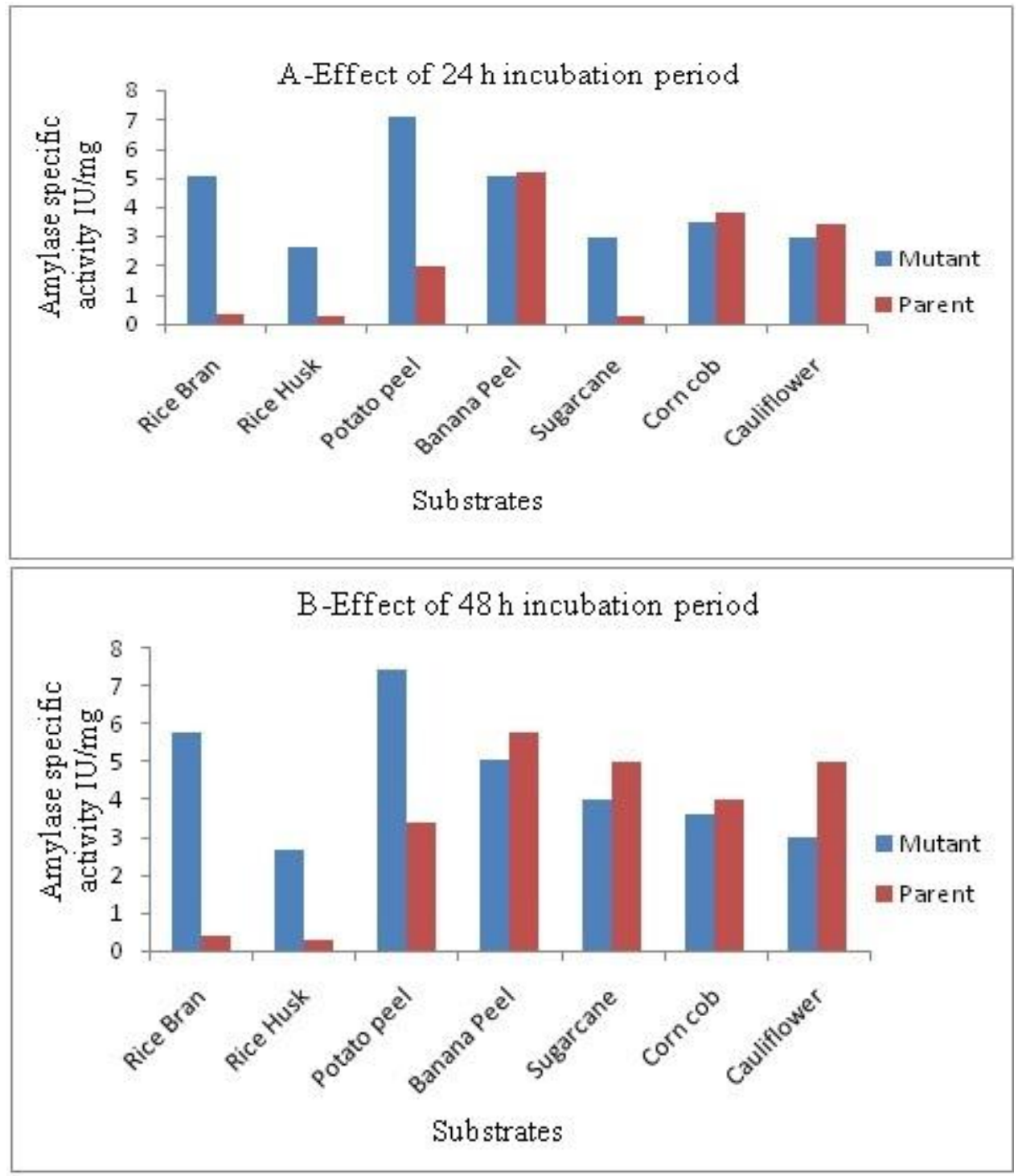



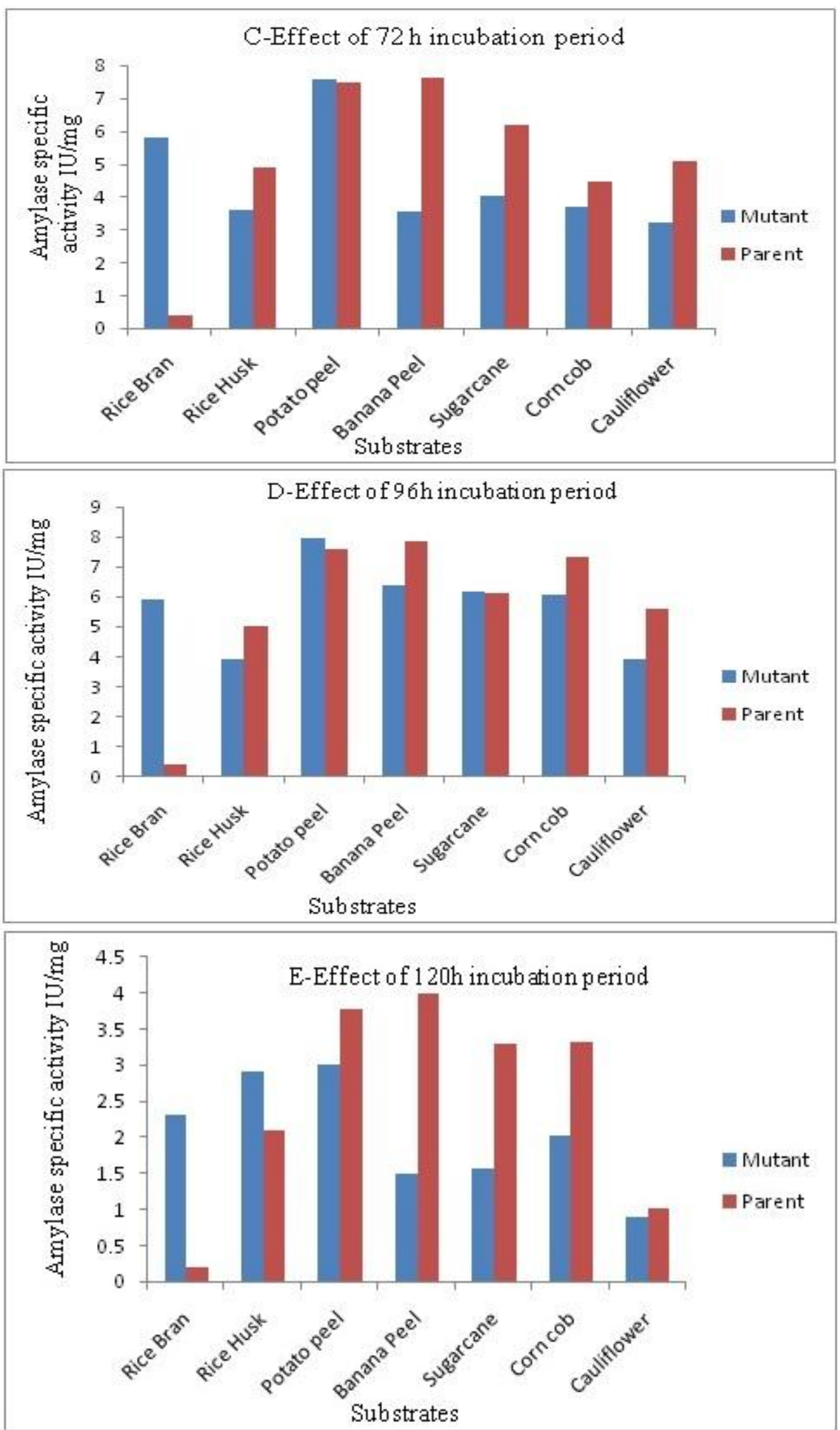

Effect of incubation period on $\alpha$-amylase production in solid state fermentation: A-24 h, B- $48 \mathrm{~h}$, C-72h, D- $96 \mathrm{~h}$ and E- $120 \mathrm{~h}$. 
Fig.4 Effect of $\mathrm{pH}$ on parent and mutant strains

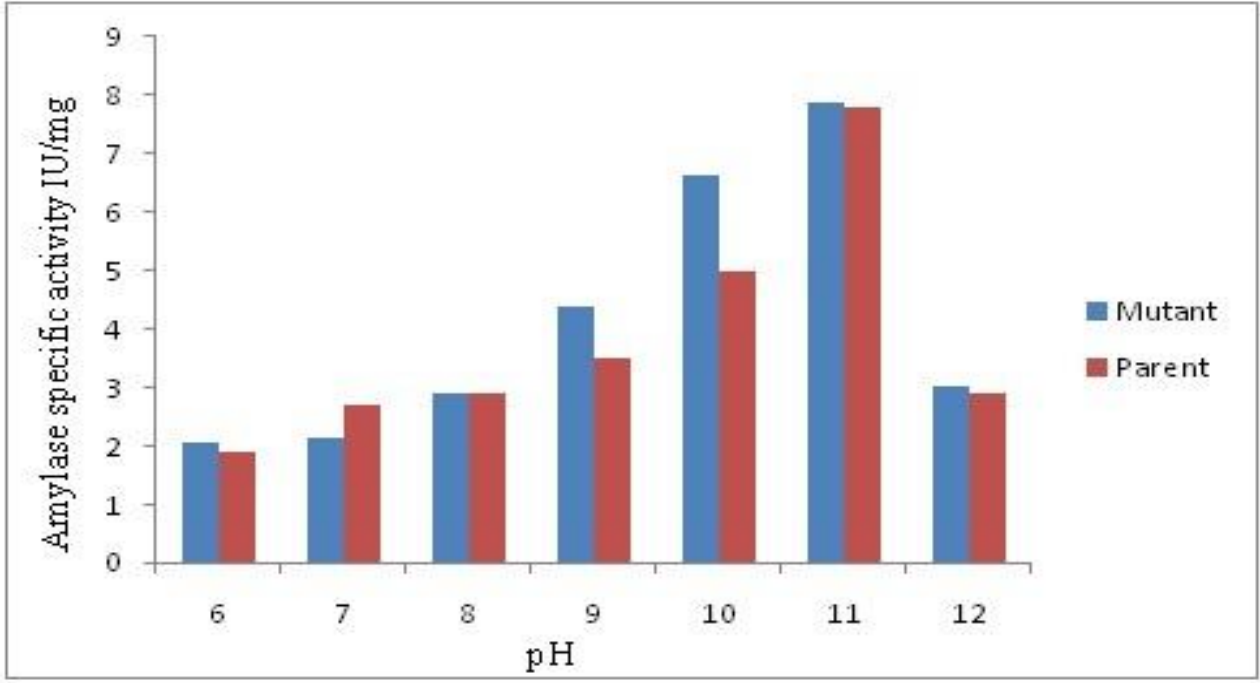

Fig.5 Effect of temperature on parent and mutant strains

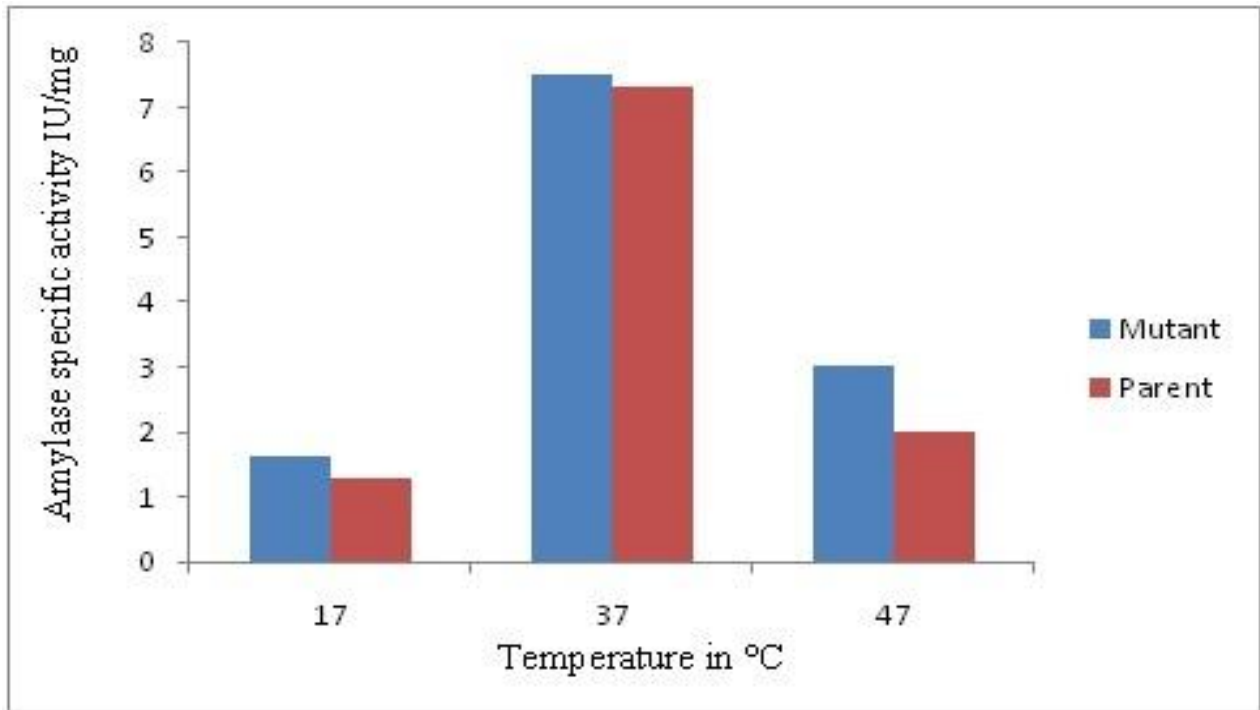

Fig.6 Effect of inoculum size on parent and mutant strains

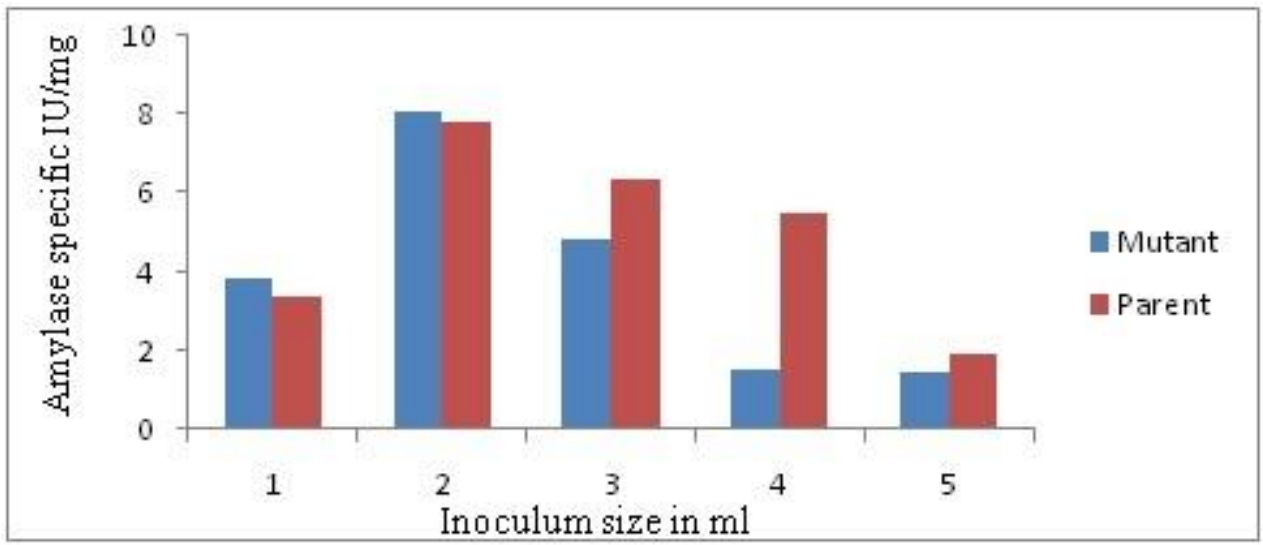


Fig.7 Effect of carbon sources $(0.2 \%)$ on parent and mutant strains

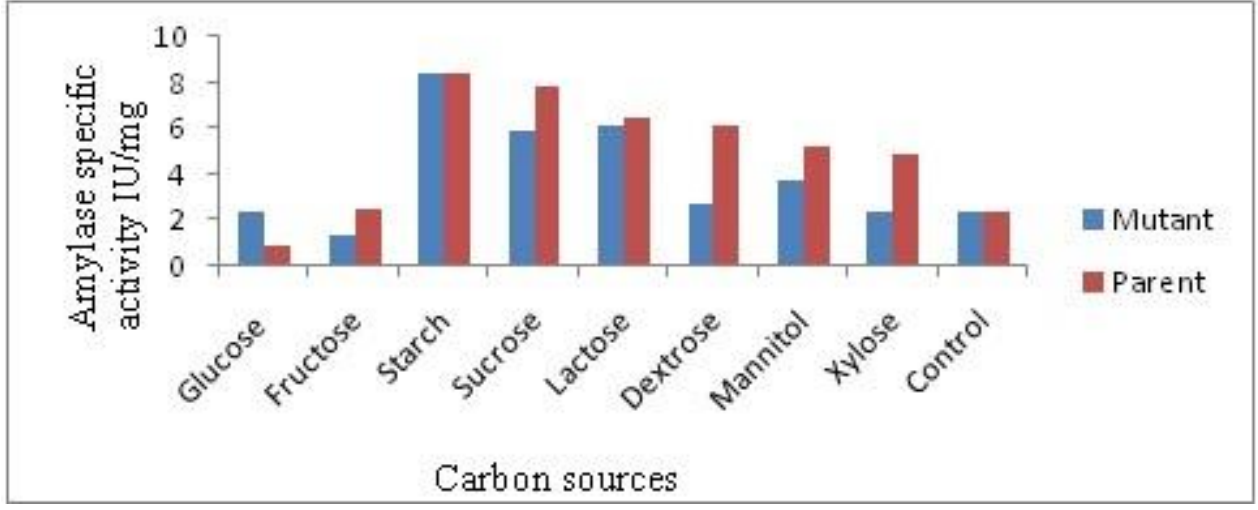

Fig.8 Effect of nitrogen sources $(0.2 \%)$ on parent and mutant strains

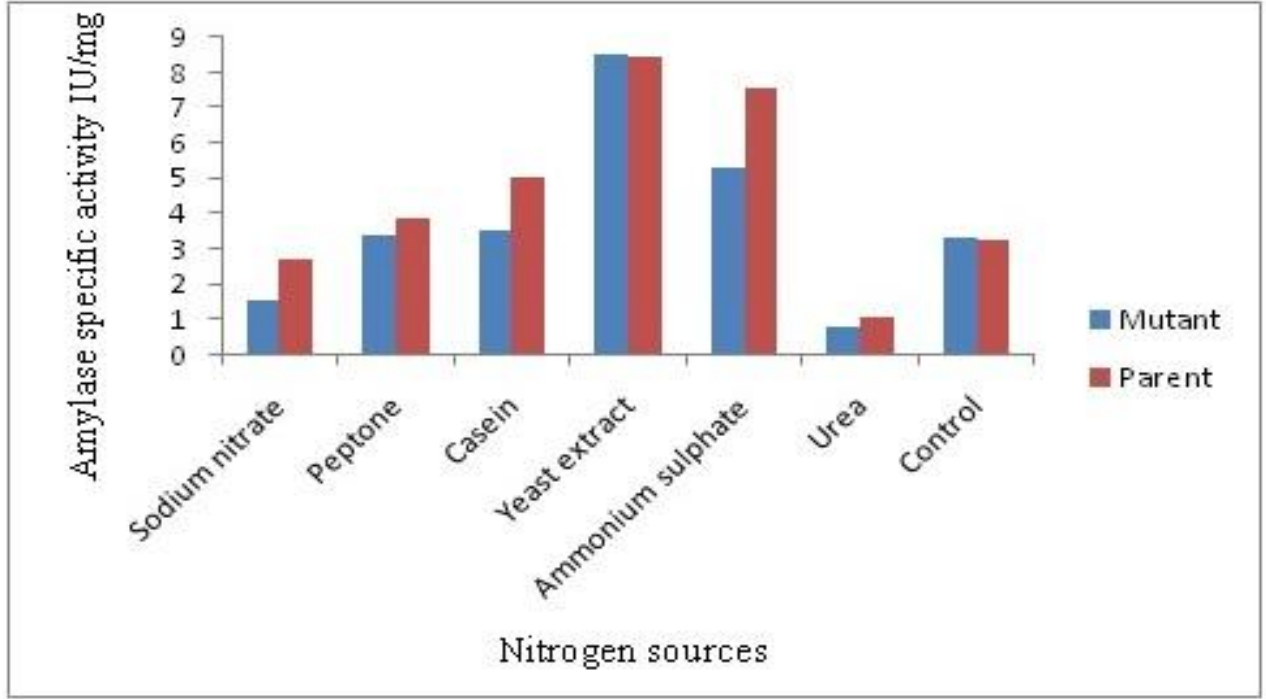

Fig.9 Effect of mineral chlorides $(0.2 \%)$ on parent and mutant strains

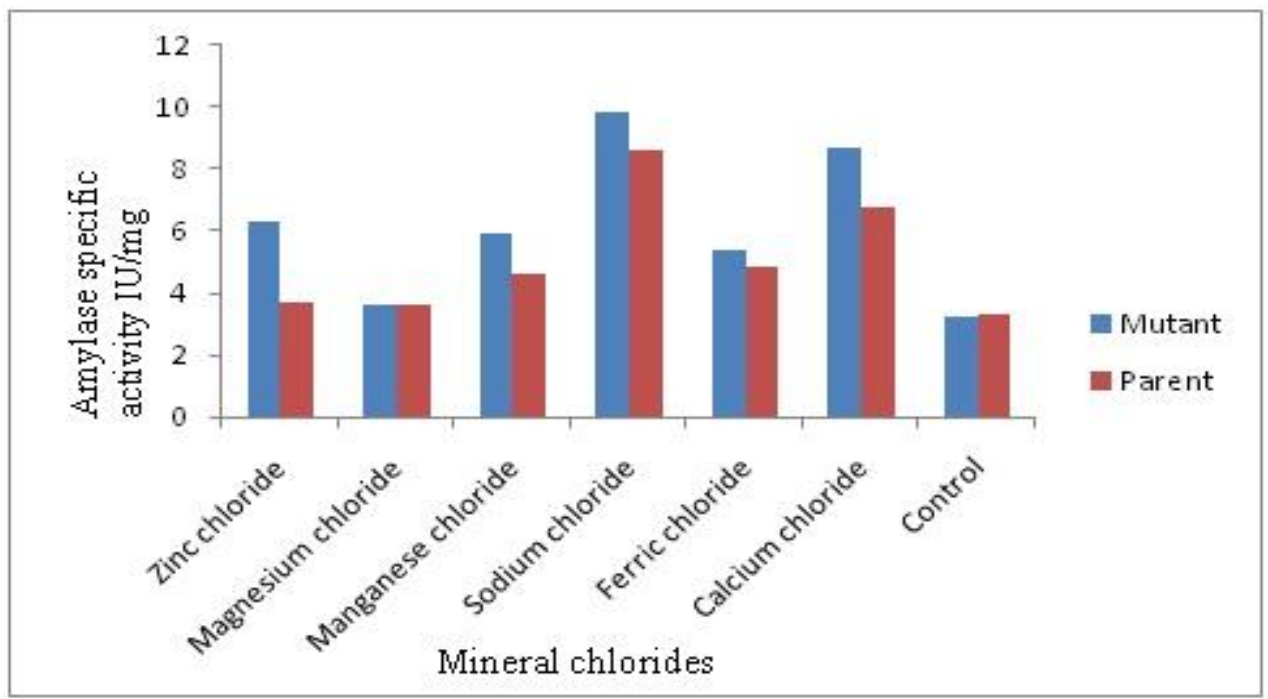


Fig.10 TLC analysis

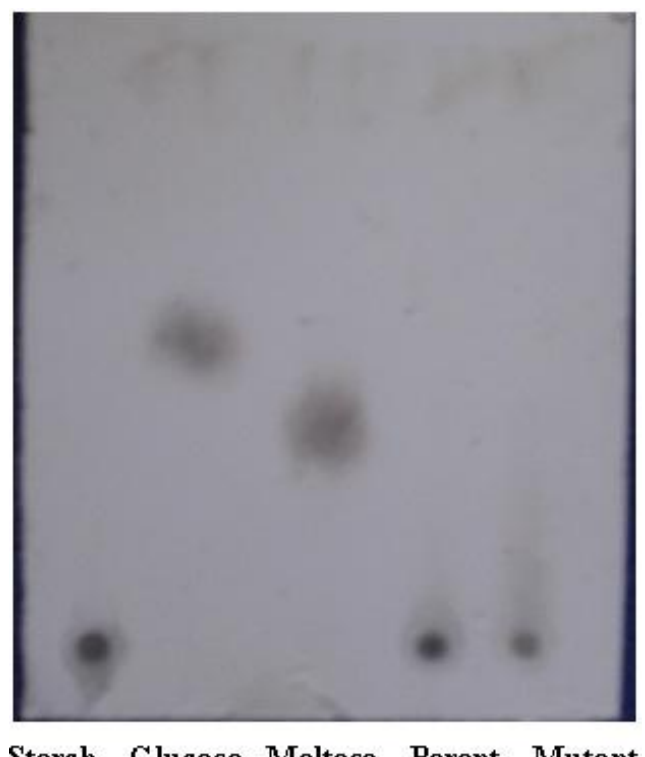

Effect of various process parameters on amylase production

Enzyme production depends on many factors that are directly proportional to the growth of the microorganisms. The bacterial isolates: parent (CHB7) and mutant $(\mathrm{MCH} / 40)$ strains were investigated for the higher production of alkaline amylase in varied incubation period which revealed that maximum production was shown at $96 \mathrm{~h}$ of incubation by CHB7 (7.87 IU/mg) and $\mathrm{MCH} / 40(7.93 \mathrm{IU} / \mathrm{mg}$ ) using banana peel and potato peel respectively at $37{ }^{\circ} \mathrm{C}$ (Fig. 3). After that there was a slight decrease of amylase production at $120 \mathrm{~h}$ which may be due to lack of nutrients and changes in medium $\mathrm{pH}$. Maximum production of alkaline amylase was seen at $\mathrm{pH} 11.0$ by CHB7 (7.78 IU/mg) and mutant $\mathrm{MCH} / 40$ (7.89 IU/mg) (Fig. 4).

The amylase production was maximum at 37 ${ }^{\circ} \mathrm{C}$ for $\mathrm{CHB} 7(7.33 \mathrm{IU} / \mathrm{mg}$ ) and mutant $\mathrm{MCH} / 40$ (7.51) (Fig. 5). Maximum production of amylase at $37{ }^{\circ} \mathrm{C}$ has also been reported (Haq et al., 2010). A concentration of $2 \mathrm{ml}$ showed highest production of alkaline amylase for CHB7 (7.79 IU/mg) and mutant $\mathrm{MCH} / 40$ (8.0 IU/mg) respectively (Fig. 6). A similar finding where $1.5 \mathrm{ml}$ inoculum of bacterial culture produced maximum amount of $\alpha$ amylase has been reported (Haq et al., 2012).

From the quantitative study (Fig. 7) it was observed that amylase production was more on starch than any other carbon sources which corroborates with the findings of Tsegaye and Gessesse (2014). CHB7 and MCH/40 showed higher production of amylase of $8.399 \mathrm{IU} / \mathrm{mg}$ and $8.372 \mathrm{IU} / \mathrm{mg}$ on starch respectively. From figure 8 it was observed that yeast extract showed the highest amylase production for CHB7 (8.44 IU/mg) and mutant $\mathrm{MCH} / 40$ $(8.55 \mathrm{IU} / \mathrm{mg}$ ) respectively as compared to the other nitrogen sources. Similar finding was also reported previously by Bhattacharya et al., (2011).

In presence of $\mathrm{NaCl}, \mathrm{CHB} 7$ (8.619 IU/mg) and $\mathrm{MCH} / 40(9.876 \mathrm{IU} / \mathrm{mg})$ showed higher production of amylase (Fig. 9). Using thinlayer chromatographic analysis, it was ascertained that the amylase produced by our 
bacterial cultures was $\alpha$ amylase owing to the presence of maltose and very low amounts of other oligosaccharides as the main endproducts of starch hydrolysis (Fig. 10). The mutant produced higher alkaline amylase than the wild strain showing 1.245 fold increase as compared to wild strain showing an increase of 1.095 fold.

This research work contributes towards the development of an economical alkaline $\alpha$ amylase production process (solid state fermentation) using agro-industrial residue.

\section{Acknowledgement}

The authors are thankful to Dr. B. B. Mishra, HOD, Microbiology Department, O.U.A.T for providing laboratory facilities during the period of study. The authors have no conflict of interest to declare.

\section{References}

Akpor, O.B., Okoh, A.I. and Babalola, G.O. 2006. Cultural microbial population dynamic during decomposition of Theobroma cacao leaf litters in tropical soil setting, J. Biol. Sci., 6(4): 768 - 774.

Aygan, A., Arikan, B., Korkmaz, H., Dincer, S. and Colak, O. 2008. Highly thermostable and alkaline $\alpha$-amylase from a halotolerantalkaliphilic Bacillus sp. AB68, Braz. J. Microbiol., 39: 547553.

Bajpai, P. and Bajpai, P. 1989. Hightemperature alkaline alpha-amylase from Bacillus licheniformis TCRDCB13. Biotechnol. Bioeng. 33: 72-78.

Bhattacharya, S., Bhardwai, S., Das, A., and Anand, S. 2011. Utilization of sugarcane Bagasse for solid state fermentation and characterization of $\alpha$ amylase from Aspergillus flavus isolated from Muthupettai mangrove, Tamil Nadu. Aust. J. Basic. Appl. Sci.
5(12): 1012-1022.

Bryant, T.N. 2003. PIBWin-software for probabilistic identification, J. Appl. Microbiol. 97(6): 1326 - 1327.

Fogarty, W.M., Dooylc, E.M. and Kelly, C.T. 1999. Comparison of the action pattern of two high maltose forming alphaamylase on linear maltooligosaccharides. Enzyme Microb. Technol. 25: 330-335.

Gupta, R., Gigras, P., Mohapatra, H., Goswami, V.K. and Chauhan, B. 2003. Microbial $\alpha$ amylases: a biotechnological perspective, Process Biochem. 38(11): 1599-1616.

Haq, I., Ali, S., Javed, M.M., Hameed, U., Saleem, A., Adnan, F., and Qadeer, A.M. 2010. Production of $\alpha$ - amylase from a randomly induced mutant strain of Bacillus amyloliquefaciens and its application as a desizer in textile industry. Pak. J. Bot. 42 (1): 473-484.

Haq, I., Hameed, U., Mahmood, Z., and Javed, M.M. 2012. Solid state fermentation for the production of $\alpha$ amylase by Paenibacillus amylolyticus. Pak. J. Bot. 44: 341-346.

Hewitt, C. J. and Solomons, G. L. 1996. The production of alpha-amylase (E.C:3. 2. 1. 1.) by Bacillus amyloliquefaciens, in a complex and a totally defined synthetic culture medium. J. Ind. Microbiol. 17: 96-99.

Horikoshi, K. 2006. Alkaliphiles: Genetic Properties and Applications of Enzymes, Springer-Verlag, Berlin and Heidelberg Gmb $\mathrm{H}$ and Co. KG.

Jackson, M.L. 1967. Soil chemical analysis, Prentice Hall of India, Pvt. Ltd., New Delhi, 498.

Kirk, O, Borchert, T.V., and Fuglsang, C.C. 2002. Industrial enzyme applications, Curr. Opin. Biotechnol. 13: 345-351.

Lowry, O.H., Rosebrough, N.J., Farr, A.L. and Randall, R.J. 1951. Protein measurement with the folin phenol 
reagent, J. Biol and Chem. 193: 265275.

Miller, G.L. 1959. Use of Dinitrosalicylic acid reagent for determination of reducing sugar. Anal. Chem. 31: 426428.

Mukherjee, A.K, Borah, M., and Rai, S.K. 2009. To study the influence of different components fermentable substrates on induction of extracellular $\alpha$ amylase synthesis by Bacillus subtilis DM-03 in solid state fermentation and exploration of feasibility for inclusion of $\alpha$ amylase in laundry detergent formulations. Biochem. Eng. J. 43: 149-156.

Niehaus, F., Bertoldo, C., Kähler, M., and Antranikian, G. 1999. Extremophiles as a source of novel enzymes for industrial application. Appl. Microbiol. Biotechnol. 51: 711-729.

Olsen, H.S., and Falholt, P. 1998. The role of enzymes in modern detergency, $J$. Surfactants Deterg. 1: 555-566.

Sajjad, M. and Choudhry, S. 2012. Effect of starch containing organic substrates on alpha amylase production in Bacillus strains. Afr. J. Microbiol. Res. 6(45): 7285-7291.
Schallmey, M., Singh, A., and Ward, O.P. 2004. Developments in the use of Bacillus species for industrial production, Can. J. Microbiol. 50: 1-17.

Singh, S., Sharma, V., and Manohar, L.S. 2013. Effect of UV induced mutation on amylase producing potential of Bacillus subtilis (2620). Int. J. Pharma Bio Sci. 4 (3): 62-68.

Singh, S., Sharma, V., Soni, M.L., and Das, S. 2011. Biotechnological applications of industrially important amylase. Int. J. Pharma Bio Sci. 2(1): 487-496.

Sivaramakrishnan, S., Gangadharan, D., Naampoothiri, K.M., Socool, C.R. and Pandey, A. 2006. Alpha amylases from microbial sources - an overview on recent developments. Food Technol. Biotechnol. 44: 173-184.

Tsegaye, K.N., and Gessesse, A. 2014. Amylase production under solid state fermentation by a bacterial isolate W74. Afr. J. Biotechnol. 13(21): 2145-2153.

Unakal, C., Kallur, R.I. and Kaliwal, B.B. 2012. Production of $\alpha$-amylase using banana waste by Bacillus subtilis under solid state fermentation. Eur. J. Exp. Biol. 2(4):1044-1052.

\section{How to cite this article:}

Allampalli Sirisha, Sonali Priyadarshini and Pratima Ray. 2017. Production and Improvement of Alkaline $\alpha$ - Amylase by Bacterial Isolate from Chilika Lake. Int.J.Curr.Microbiol.App.Sci. 6(7): 2769-2781. doi: https://doi.org/10.20546/ijcmas.2017.607.387 